\title{
A REALIDADE CARCERÁRIA BRASILEIRA E O PAPEL DAS APACS COMO POSSÍVEIS VIAS DE RESSOCIALIZAÇÃ̃ ${ }^{1}$
}

THE BRAZILIAN PRISON REALITY AND THE ROLE OF APACS AS POSSIBLE WAYS OF RESOCIALIZATION

Milena Ivan de SOUZA ${ }^{2}$

ISSUE DOI: 10.21207/2675-0104.2019.937

\begin{abstract}
RESUMO
Por motivos históricos, econômicos, teóricos e sociais, o atual sistema penitenciário brasileiro enfrenta uma séria crise de funcionamento (resultado, dentre outros fatores, de superlotação, rebeliões e falta de higiene básica). A função ressocializadora desse sistema, amparada por tratados internacionais bem como por leis nacionais, principalmente a Lei de Execução Penal, é raramente alcançada pelos presídios comuns e, com isto, toda a sociedade padece de uma constante insegurança social e de aumento da violência nas ruas. A proposta da pesquisa é demonstrar o distanciamento entre o sistema ideal de prisões - caso fossem respeitados os parâmetros legais e constitucionais - da realidade em que se inserem. Em meio a esse cenário de caos e violação sistemática de direitos humanos, em 1972 surgiu um modelo novo de presídios, elaborado por Mário Ottoboni, chamado de Associação de Proteção e Assistência aos Condenados (APAC), que se propôs a trabalhar com apenados, lá chamados de recuperandos, com suas famílias e com suas comunidades de forma humana e respeitando suas dignidades, e, como resultado, obtiveram números satisfatórios, quando comparados com o sistema comum, que levam ao questionamento da suficiência do cumprimento da pena para a ressocialização do indivíduo e a crença ser esta uma via alternativa para a amenização dos danos e dos problemas que agravam o cenário dos presídios brasileiros.
\end{abstract}

\footnotetext{
${ }^{1} \mathrm{O}$ presente artigo sintetiza a monografia de conclusão da pesquisa, realizada para o Programa Interno de Bolsas de Iniciação Científica (PIBIC 2018-2019) da Faculdade de Direito de Franca (FDF), Franca/SP.

${ }^{2}$ Discente da Faculdade de Direito de Franca (FDF), Franca/SP. Bolsista do Programa Interno de Bolsas de Iniciação Científica (PIBIC 2018-2019).
} 
Palavras-chave: Pena privativa de liberdade. Crise. Lei de Execução Penal. APAC. Ressocialização.

\section{ABSTRACT}

Because of historical, economical, theoretical and social reasons, the current penitentiary system faces a serious operation crisis (as a result, between other factores, of over crowding, rebelions and lack of basic hygiene). Its function of ressocialization, suported by international treats and national laws, mainly by de Penal Execution Law, it's rarely reached by the ordinary prisons and, with this, the whole society suffer of a Constant social insecurity and street violence increase. The research proposal is to demonstrate de distance from the ideal prison system - if the laws and constitution were respectedto the settled reality. Amid this chaos and systematic violation of the human rights's scenario, in 1972, a new prison model emerged, created by Mário Ottoboni, called Association of Protection and Assistence to the Condemned (APAC), that set out to work with convicted, in process of recuperation, their families and their comunities humanly, respecting their dignities, and, as a result, they obtained satisfactory numbers when compared to the ordinary prison system, wich lead us to question the penalty's competence to ressocialize and to believe that this metodology may be and alternative path to the amenization of the damage and issues that aggravate the brazilian prisons scenario.

Keywords: Deprivation of liberty. Crisis. Penal Execution Law. APAC. Ressocialization,

\section{INTRODUÇÃO}

As penas e presídios passaram por grandes evoluções no decorrer da História, passando de suplícios até a "racionalidade penal", de acordo com o desenvolvimento da sociedade e com sua busca por segurança pública.

Após a Idade Média, em que as penas eram muito atreladas à ideia de suplício, surgiram os primeiros modelos de cadeias, que intencionavam retirar o indivíduo da sociedade temporariamente e, posteriormente, devolvê-lo ao convívio comunitário munido de moral. Gradativamente, este modelo foi se aperfeiçoando em tese, chegando ao que temos hoje, com legislações e tratados internacionais específicos para sua regulamentação e padronização de seu funcionamento interno.

Neste contexto, todavia, o Sistema Prisional Brasileiro encontrase em decadência nos presentes dias, decadência esta que afeta não somente sua estrutura física, mas, principalmente, a obtenção de êxito em seu objetivo principal: a ressocialização do preso.

Superlotados, os presídios são assombrados por rebeliões internas, propagação de doenças, formação de grupos criminosos autorizados, abuso de poder estatal e, neste cenário, pergunta-se: em que ponto se perdeu a medida da condenação? Como se justifica a banalização da pena privativa de liberdade? De fato, o sistema de justiça criminal brasileiro necessita de maiores reflexões, de forma a levantar pontos críticos e propostas de mudança com relação à crise institucional e 
humanitária que o caracteriza. É neste contexto, de busca por alternativas aos modelos tradicionais de execução das penas privativas de liberdade, que surgiu o método da Associação para a Proteção e Assistência aos Condenados (APAC), orientado à proteção dos direitos do condenado e que mantém em perspectiva os desafios de reinserção social do sujeito preso. Todavia, restam indagações sobre as potencialidades desses métodos para servirem como vias para a redução de danos e da crise no sistema.

Destarte, propõe-se a pesquisa a enfrentar duas perguntasproblema: (i) "de que modo as condições concretas de execução das penas privativas de liberdade no Brasil afetam a reinserção social do indivíduo, como finalidade da pena a ser perseguida?"; e (ii) "seriam as APACs uma efetiva alternativa aos problemas do sistema carcerário brasileiro, especialmente às dificuldades que este enfrenta no que concerne à ressocialização dos condenados?"

Através do método dedutivo e valendo-se da revisão sistemática de bibliografia como estratégia de pesquisa, o trabalho buscará em seu primeiro capítulo, esclarecer o caminho percorrido politicamente para que as prisões se tornassem o que atualmente são, como a insegurança social se verteu em políticas de repressão e opressão (as políticas de "Tolerância Zero"), focando-se, por fim, na conjuntura brasileira.

Em seu segundo capítulo, analisará o ordenamento vigente que sustenta os parâmetros que as prisões, especialmente no Brasil bem como no mundo, deveriam seguir. Especialmente como seu funcionamento, estrutura, normas e tratamento para com os presos deveriam ser humanizados, sem afastá-los de sua dignidade no período em que cumprem suas sentenças.

Após, no terceiro capítulo, analisar-se-ão alguns dos problemas enfrentados no Brasil em sua realidade carcerária, tais como a falta de estrutura física, a superlotação em si, a perseguição à grupos minoritários, falta de assistência em presídios femininos, entre outros problemas que, juntos, trouxeram a decretação de um estado inconstitucional de coisas através do julgamento da ADPF 347 pelo Supremo Tribunal Federal (STF).

Por fim, o quarto capítulo se prestará a trazer ao conhecimento as origens da APAC - e seus principais fundamentos, discutindo-se os porquês da defesa da metodologia apaqueana como possível remédio para a falência iminente do sistema prisional brasileiro. 


\section{A POLÍTICA DE SUPERENCARCERAMENTO}

Com a ascensão de governos neoliberais, arraigados à ideologia do mercado-total influenciada principalmente pelos Estados Unidos da América, nota-se a elevação do Leviatã como ser onipotente e capaz de combater toda delinquência em seu solo. Por isso, as prerrogativas do Estado na frente econômica e social foram diminuídas e transferidas às missões de "segurança", ou seja, adotou-se uma política de repressão policial para a limpeza das ruas, supostamente contaminadas por infratores, ao invés de adotar-se políticas sociais para diminuição da desigualdade social e econômica ${ }^{3}$.

A cada dia, o número de encarcerados aumenta enquanto, paralelamente, aumenta a vigilância policial; e grande parte do aumento dos números de presos no sistema deve-se ao fato de que a pena de prisão é a mais utilizada forma de controle de social sob a população menos favorecida.

Em sua obra, o autor David Garland usa o termo "mass imprisonment" para descrever a instituição que emergiu nos Estados Unidos nas duas últimas décadas e que, no ano de 2001, teria elevado o número de presos e encarcerados a mais de 2.000.000 pela primeira vez. De acordo com o autor, este fenômeno não possui precedentes na América, tendo como parâmetro apenas países orientais autoritários, como China e Rússia.

Então, quais seriam as características do "mass imprisonment"? Para Garland, existem duas características essenciais neste fenômeno, a primeira trata apenas de números, o mass imprisonment implica uma taxa de população carcerária marcadamente acima de qualquer comparação histórica já registrada. A outra é uma soma de efeitos do aprisionamento "normal", ou seja, o aprisionamento se torna aprisionamento em massa quando aquele para de ser a prisão individual do ofensor e passa a ser a prisão sistemática de todo um grupo da população ${ }^{4}$.

Nas últimas décadas do século XX, marcadas por amplas transformações históricas, econômicas e sociais, o autor menciona os

\footnotetext{
${ }^{3}$ WACQUANT, Loïc. As prisões da miséria. Tradução André Telles; tradução à introdução da introdução à segunda edição e do prefácio Maria Luiza X. de A. Borges. 2 ed. Rio de Janeiro: Zahar. 2011. p. 12.

4 GARLAND, David. Mass Imprisonment: Social Causes and Consequences. Londres: Sage Publications, 2001. p. 1/2.
} 
processos de globalização que mobilizaram capital, tecnologia e informação da mesma forma que mobilizaram importantes parcelas da população, e, por meio do encarceramento e da exclusão social, atribui a elas as mudanças nas políticas de controle do crime, bem como o clamor social que as apoiam; a sociedade adentrara, então, ao momento que Garland chamou de "modernidade tardia" e, nela, surgiram teorias do controle que passaram a traçar o homem de forma obscura, levados por condutas antissociais, a menos que fossem impedidos por controles efetivos, dando autoridade à família, à comunidade e, por fim, ao Estado para estabelecerem e imporem-lhes restrições e limites ${ }^{5}$.

Com estas mudanças estruturais ocorridas na sociedade, Garland aponta que a reinvenção das prisões como controle criminal foi sua principal conseqüência. As prisões, para ele, atualmente são usadas como uma zona de quarentena onde indivíduos supostamente perigosos são segregados em nome da segurança pública ${ }^{6}$. O Estado se fortalece penalmente ao utilizar as prisões como forma de controle social e, este controle recai, principalmente, sobre as populações menos favorecidas. Esta perseguição e exclusão dos grupos mais afetados pelas mudanças sociais e econômicas, dependentes de previdência social e das minorias, é o que o autor supracitado chamou de "cultura do controle"7.

Portanto, vê-se que o recrudescimento securitário e a repressão de grupos minoritários da sociedade pouco refletem na contensão da violência e no incremento da segurança pública, ao passo que muito custam aos cofres públicos, às políticas sociais e, principalmente, à dignidade humana de toda a população que agoniza nas ruas ou nas prisões.

O que hoje conhecemos como prisões, chamadas por Foucalt de "punição da modernidade", se tornou a principal protagonista desta política de "limpeza das ruas", a única via para a solução do conflito violento entre a sociedade, sem muitos questionamentos sobre seus métodos e critérios de encarceramento ${ }^{8}$.

Mesmo com a Declaração Universal dos Direitos Humanos cerceando de maneira explícita o que o Estado deveria considerar ao encarcerar um indivíduo, atualmente, tanto em países desenvolvidos, como

\footnotetext{
${ }^{5}$ GARLAND, David. The culture of control: crime and social order in contemporary society. Oxford: University Press, 2001, p. 178

${ }^{6}$ Ibidem.

${ }^{7}$ Ibidem. p. 195.

${ }^{8}$ IBCCRIM. Política de drogas, cultura do controle e propostas alternativas. São Paulo, 29 abr. 2009. Disponível em: <https://www.ibccrim.org.br/noticia/13270-Politica-de-drogas-cultura-docontrole-e-propostxas-alternativas >. Acesso em: 26/06/2019.
} 
os Estados Unidos, quanto os em desenvolvimento, como o Brasil, observa-se uma enorme crise no sistema que culmina no aprisionamento dos indivíduos.

A relação entre crime e encarceramento se tornou simplória, banalizada, ignorando os fatores que influenciam os comportamentos individuais. Como incisivamente postulou Sérgio Salomão Shecaira, com a entrada da modernidade, as relações entre indivíduos se alteraram (não somente dos indivíduos como civis, ou em comunidade, mas também entre cônjuges, emprego, etc.), a anterior rotina natural (comunitária) fora substituída por uma artificial, individualista, e trouxe consigo uma sensação de insegurança (insegurança no trabalho, na relação familiar estável, na assistência em momentos de fragilidade) que culminou na exigência de uma força compensadora de estabilidade, para clarear os papeis de vida comunitária, apta, ilusoriamente, a criação de mecanismos para a eliminação do crime e da criminalidade. Alguns mecanismos de exacerbação de punição podem ser citados: o Direito Penal do Inimigo, o Movimento Lei e Ordem e a Tolerância Zero, todos com várias formas de fobias raciais9, todos intencionados a maximizar a intervenção punitiva.

Concernente a esta problemática, focar-se-á na política da "Tolerância Zero", esta que, de acordo com Shecaira, além de ser parte do processo encarcerador (junto com os outros movimentos supracitados) é uma estratégia policial de monitoramento e reforça a descrença de que um egresso do sistema punitivo possa ser reinserido na sociedade, esvai a busca pelas razões sociais sobre as quais o indivíduo recorre ao crime e deixa de prezar pela superação do processo de exclusão social. Com essa política, todo e qualquer tipo de infração passou a ser reprimido, inclusive os insignificantes. Moradores de rua, pedintes de semáforos, grafiteiros, todos passaram a ser perseguidos e mandados para abrigos, considerados como obstáculos ao funcionamento dos negócios ${ }^{10}$, tornando as prisões em um grande alojamento de minorias, negros, desempregados, excluídos e marginalizados.

O que se nota, pois é que há certo descaso por parte do poder estatal frente à realidade estrutural da sociedade, tornando as prisões similares a um grande campo de concentração, onde os já sentenciados e os que ainda aguardam seu veredicto se misturam, aumentando o número

\footnotetext{
${ }^{9}$ SHECAIRA, S.S. Tolerância zero. Revista Brasileira de Ciências Criminais, São Paulo: IBCCrim/RT, n. 77, p. 261-280, 2009. p. 168/170.

10 SHECAIRA, S.S. Tolerância zero. Revista Brasileira de Ciências Criminais, São Paulo: IBCCrim/RT, n. 77, p. 261-280, 2009. p. 171.
} 
de presos sem a readaptação dos presídios que os acolhem, tampouco uma reforma no sistema carcerário, e, visto a inefetividade e incapacidade de ressocialização do indivíduo deste, todas as suas perspectivas de melhora social dos encarcerados, lhes são retiradas à força.

Sem a devida ressocialização, o criminoso que cumpriu sua pena é liberto e torna a prática de crimes, o que, eventualmente, o levará novamente à prisão, criando, assim, o ciclo vicioso do encarceramento.

\subsection{REFLEXOS NO CENÁRIO BRASILEIRO}

No Brasil, faz-se presente uma sociedade caracterizada pelas disparidades sociais vertiginosas e pela pobreza de massa, que, combinadas, geram um aumento inexorável da violência criminal, rebaixando grandes e importantes cidades brasileiras à pólos de insegurança criminal.

A insegurança gerada pela violência, no Brasil, além de não contar com políticas de atenuação, é agravada pelo uso pela polícia das chamadas "forças de ordem", que normalizaram a violência letal, execuções sumárias e "desaparecimentos", gerando um clima de maior terror entre o povo e banalizaram a violência praticada pelo Estado.

O combate exacerbado aos "indesejados" no Brasil, entretanto, não teve inicio nos últimos anos, mas, agravou-se no decorrer das décadas, sob a influência do punitivismo neoliberal, passou a objetivar uma maior presença de um Estado policial e penitenciário e menor nos setores da economia e social ${ }^{11}$, segundo Débora Pastana:

Mesmo considerando as particularidades nacionais, alguns estudos recentes apontam para dados que nos permitem afirmar que o Brasil também aderiu recentemente ao modelo de gestão penal neoliberal. Cada vez mais afeito a esse modelo de "estado mínimo", o Brasil adotou o que Lamounier e Souza (2006, p. 48) denominaram "democracia tutelada". Segundo os autores, para orquestrar o desmanche estatal sem contestações políticas capazes de reverter o processo, o estado "testa até o limite o regime democrático, mas não o suprime em termos estritamente legais"12

\footnotetext{
${ }^{11}$ Ibidem, p. 09.

12 PASTANA, Débora Regina. Estado punitivo brasileiro. A indeterminação entre democracia e autoritarismo. Civitas-Revista de Ciências Sociais, v. 13, n. 1, 2013. p. 36.
} 
Segundo Wacquant, esta forma de punião visa "regular (...) e perpetuar a pobreza e armazenar os dejetos humanos do mercado" "13; reafirmando o "punho de ferro" do Estado e a "mão invisível" do mercado $^{14}$, angariando, cada dia mais, um aumento do número de simpatizantes dessa corrente nas elites empresárias.

Além do supracitado, a mídia também contribuiu no aumento do terror da sociedade, noticiando com grande veemência e sensacionalismo tanto os pequenos quanto os grandes crimes, gerando identificação entre os telespectadores e, aos poucos, foi criando um "retrato falado" do inimigo que pairava sobre as ruas; sobre o papel da mídia, assim discutiram os autores Décio Franco David e Jaqueline Alexandra Maccoppi, em seu artigo "Punitivismo pós-moderno: hipertrofia penal e fetiche punitivo pela mídia e discurso de crise":

Os meios de comunicação em massa, como grandes instrumentos de difusão cultural e de controle social geral, reproduzem inúmeros discursos que importam na formação do senso comum. A mídia é capaz de criar e transformar valores e padrões de pensamento para atender a determinados modelos por intermédio do empobrecimento do imaginário e do simbolismo ${ }^{15}$

Por conseguinte, sem pensamento crítico e impelidos por discursos violentos de apresentadores televisivos (majoritária, mas não exclusivamente), a sociedade passou a cobrar cada vez mais que os chamados "crimes de rua" ensejassem em penas desproporcionais, bradando em alta voz por punição e leis mais severas no combate à criminalidade e majorando, assim, a perseguição e repressão estatal.

Somando-se então, a desigualdade social brasileira à influência política de países desenvolvidos e à propagação midiática do ódio às minorias, a repressão estatal aumenta, porém, sem reduzir a situação violenta do país.

Segundo dados fornecidos pela $\mathrm{OMS}^{16}$, o Brasil ocupa a sétima posição no ranking mundial de maiores taxas de homicídio, enquanto dados

\footnotetext{
${ }^{13}$ WACQUANT, Loïc. As prisões da miséria. Tradução André Telles; tradução à introdução da introdução à segunda edição e do prefácio Maria Luiza X. de A. Borges. 2 ed. Rio de Janeiro: Zahar. 2011. p. 11.

${ }^{14}$ BOLDT, Raphael; KROHLING, Aloísio. Direitos humanos, tolerância zero: paradoxos da violência punitiva no estado democrático de direito. Prisma Jurídico, v. 10, n. 1, p. 33-48, 2011.

${ }^{15}$ DAVID, Décio Franco; MACCOPPI, Jaqueline Alexandra. Punitivismo pós-moderno: hipertrofia penal e fetiche punitivo pela mídia e discurso de crise. Boletim IBCCRIM, São Paulo, v. 26, n. 311, p. 12-13., out. 2018.

${ }^{16}$ Disponível em: <https://nacoesunidas.org/brasil-sobe-duas-posicoes-e-passa-a-ter-7a-maior-taxade-homicidios-das-americas-diz-oms/>
} 
do Departamento Penitenciário Nacional ${ }^{17}$, em junho de 2016 (último dado tabulado), indicaram que, no Brasil, há 726.712 pessoas presas, dado este que elevou o país ao $3^{\circ}$ colocado no ranking mundial dos países com o maior número de pessoas presas.

Portanto, nota-se que a trajetória do desenvolvimento das penas trouxe ao modelo de aplicação que atualmente se vê; no Brasil, percebe-se uma soma de fatores não apenas históricos mas, inclusive, de influência política internacional que conduziu ao estado atual. Conquanto, importa destacar as peculiaridades presentes no ordenamento brasileiro que acarretaram, em conjunto, à configuração do presente cenário.

\section{EXPECTATIVA: ORDENAMENTO JURÍDICO BRASILEIRO E AS PENAS DE PRISÃO}

Posto que as prisões se tornaram mecanismos de repressão e controle penal, sendo a principal punição deste século e do passado, faz-se necessário analisar as expectativas normativas quanto a elas. Visto a verificação de discricionariedade em sua evolução, poderes públicos estabeleceram parâmetros, obrigações e deveres a serem cumpridos dentro dos presídios, para respeito das vidas ali retidas e para maior eficácia em seu funcionamento.

\subsection{ORDENAMENTOS E TRATADOS INTERNACIONAIS}

A Declaração Universal dos Direitos Humanos (DUDH) foi adotada pela ONU em 1948, no período pós-guerra, ou seja, após um longo período de violações da existência humana. Por prezar pelo respeito aos indivíduos, logo se tornou um ideal a ser atingido em todos os órgãos e nações ao redor do mundo, por isto, é de extrema e absoluta relevância, pois também interligou direitos civis a políticos, culturais, sociais e a econômicos. Entretanto, embora fosse um objetivo a ser alcançado, quando instituída, não atingia a todos os países com força normativa, nas palavras de Luciano Mariz Maia:

${ }^{17}$ MINISTÉRIO DA JUSTIÇA E SEGURANÇA PÚBLICA. Departamento Penitenciário Nacional. Levantamento Nacional de Informações Penitenciárias (INFOPEN). Brasília: 2017. Disponível em: <http://depen.gov.br/DEPEN/depen/sisdepen/infopen/relatorio_2016_22-11.pdf〉. Acesso em: 19 ago. 2019. 
(...) a Declaração não era um tratado, e não tinha força vinculante, ao momento de sua adoção. Daí a necessidade de adoção de atos internacionais com força normativa, de modo a gerar obrigações para os Estados partes, conduzindo a maior observância dos preceitos referidos na Declaração Universal ${ }^{18}$

Deste modo, os problemas ocorridos dentro de determinado Estado deixaram de ser apenas uma preocupação doméstica, visto a universalização dos direitos humanos, formando um sistema normativo global de proteção a esses direitos ${ }^{19}$.

Neste sistema normativo, há instrumentos de alcance geral (como os Pactos Internacionais de Direitos Civis e Políticos e de Direitos Econômicos, Sociais e Culturais de 1966) e de alcance específico (ou especial), como Convenções que buscam respostas à denúncias a respeito de tortura, discriminação racial, contra as mulheres, entre outros reconhecidos direitos - como à vida, segurança, liberdades (de credo, de associação, de religião, de expressão e opinião), igualdade, proteção à honra, saúde, educação, trabalho e remuneração, participação na vida cultural e política, entre outros. Sobre a integração de instrumentos gerais e específicos, Flávia Piovesan disserta:

Firma-se, assim, no âmbito do sistema global, a coexistência dos sistemas geral e especial de proteção dos direitos humanos, como sistemas de proteção complementares. O sistema especial de proteção realça o processo da especificação do sujeito de direito, no qual o sujeito passa a ser visto em sua especificidade e concreticidade (ex: protege-se a criança, os grupos étnicos minoritários, os grupos vulneráveis, as mulheres,...). Já o sistema geral de proteção (ex: Pactos da ONU de 1966) tem por endereçado toda e qualquer pessoa, concebida em sua abstração e generalidade. $^{20}$

O alcance contemporâneo de direitos humanos é, segundo Flávia Piovesan $^{21}$, universal e indivisível; universal, pois clama pela extensão universal dos direitos humanos, crendo que o fato de se tratar de uma pessoa já basta para que ela seja titular de direitos, considerando o ser humano como único e portador de dignidade; indivisível pois a garantia de direitos civis e políticos é condição para a obtenção de direitos sociais,

\footnotetext{
${ }^{18}$ MAIA, Luciano Mariz. O Brasil antes e depois do Pacto de San José. Boletim Científico-Escola Superior do Ministério Público da União. Brasília: ESMPU, Ano I, v. 4, 2002. p. 82.

${ }^{19}$ Ibidem.

${ }^{20}$ Ibidem. p. 97.

${ }^{21}$ PIOVESAN, Flavia. Direitos sociais, econômicos e culturais e direitos civis e políticos. Emilio García Méndez, 2004, p. 22.
} 
econômicos e culturais (e vice-versa), ou seja, quando um é violado, os outros também são.

No Brasil, houve um período de ditadura militar, em que as práticas recorrentes em nada respeitavam os parâmetros dos direitos humanos; havia tortura, ocultação de informações, perseguição da oposição, entre diversas outras violações.

Nas palavras de Fauzi Hassan Choukr, lê-se:

O período caracterizou-se pelo ápice do regime de exceção à democracia, quando o sistema legal existente era largamente usado para oprimir politicamente os "inimigos do regime" e no qual se utilizou amplamente a primeira LSN (Lei de Segurança Nacional) imposta com o Decreto-Lei $N^{\circ} 314$ - de 13 de março de $1967 .^{22}$ (destaque acrescentado pela autora)

Após esse período, mesmo nunca havendo uma punição de fato dos responsáveis pelas atrocidades cometidas, iniciou-se, a partir de meados da década de 70 e início da década de 80, o processo de liberalização da política, trazendo de volta, mesmo que a pequenas "doses", os direitos políticos e públicos.

Em 1985, com o início do processo de redemocratização, o Brasil novamente deu início às adesões aos pactos e convenções internacionais de proteção dos direitos humanos.

Assim foi a introdução dos direitos previstos na Convenção Americana de Direitos Humanos (CADH) no Brasil. Como consequência, houve o fim da prisão civil por dívida e a introdução de garantias judiciais, como: o direito do réu de ser ouvido dentro de um prazo razoável por um juiz ou tribunal competente, a presunção de inocência, a confissão passou a ser válida somente se ocorrida sem coação nenhuma, o preso que já cumpriu sua pena não poderia ser submetido a novo julgamento pelos mesmos fatos, a publicidade do processo penal, entre outros.

Importante ressaltar, também, que a partir de então os acusados penalmente passaram a ter uma nova fonte de legitimação jurídica para garantias mínimas de tratamento igualitário dentro do processo, tendo sua dignidade protegida de qualquer abuso de autoridade.

Segundo as palavras de VIEIRA e DUPREE:

\footnotetext{
${ }^{22}$ CHOUKR, Fauzi Hassan. A Influência da Convenção Americana de Direitos Humanos no processo penal brasileiro. Boletim Científico-Escola Superior do Ministério Público da União. Brasília: ESMPU, Ano I, n. 4, p. 111-128, 2002.
} 
Os piores abusos, omissões e transgressões são de responsabilidade do Estado, tomado aqui como a autoridade governante (polícia, judiciário, legislativo, serviços públicos e política externa) que nasce de alguma forma de pacto social. A presença e o poder da autoridade estatal são tão dominantes em todas as esferas de nossas vidas que os direitos humanos freqüentemente são concebidos como um conjunto de princípios, ou pactos, entre o Estado e os que são governados por $\mathrm{ele}^{23}$

Os abusos realizados por parte do Estado ocorrem mediante alguns de seus órgãos ou de suas instituições, perpetrado por agentes estatais que se sentem em situação de superioridade, visto que se pratica majoritariamente contra as minorias sociais; por isso é de mister importância que se avalie e se estabeleça regras aptas para coibir estas práticas antes que elas se perpetuem e se institucionalizem.

Destarte, a Organização das Nações Unidas (ONU), em seu $1^{\circ}$ Congresso, estabeleceu as Regras Mínimas de Tratamento de Prisioneiros (1955), um marco normativo disciplinador na história dos estudos da pena, que, inclusive, serviu de inspiração para a posterior promulgação da Lei de Execução Penal brasileira.

As Regras Mínimas consolidaram aquilo que posteriormente, na Constituição Federal de 1988, doutrinadores chamaram de "mínimo existencial", definido nos seguintes termos pelo STF em julgado relatado pelo Min. Celso De Mello em 2011:

\begin{abstract}
A noção de mínimo existencial, que resulta, por implicitude, de determinados preceitos constitucionais (CF, art. $1^{\circ}$, III, e art. $3^{\circ}$, III), compreende um complexo de prerrogativas cuja concretização revela-se capaz de garantir condições adequadas de existência digna, em ordem a assegurar, à pessoa, acesso efetivo ao direito geral de liberdade e, também, a prestações positivas originárias do Estado, viabilizadoras da plena fruição de direitos sociais básicos, tais como o direito à educação, o direito à proteção integral da criança e do adolescente, o direito à saúde, o direito à assistência social, o direito à moradia, o direito à alimentação e o direito à segurança. (STF, ARE 639337 AgR, Rel. Min. Celso de Mello, Segunda Turma, j. 23-8-2011, Diário da Justiça Eletrônico de 159-2011).
\end{abstract}

Sempre mantendo o foco na dignidade da pessoa humana, as Regras Mínimas se referem às condições básicas que devem ser observadas dentro dos presídios para que seja assegurado ao preso o direito à integridade física e moral.

${ }^{23}$ VIEIRA, Oscar Vilhena; DUPREE, A. Scott. Reflexões acerca da sociedade civil e dos direitos humanos. 2004. 
Portanto, vê-se que os sistemas normativos de direitos humanos interagem entre si, se complementando como direitos subjetivos dos presos, que podem invocá-los devido ao desequilíbrio de forças e poder entre Estado e indivíduo, e objetivamente, pois autorizam que os Estados punam indivíduos que não se comportem dentro destes parâmetros de respeito à dignidade humana.

Com a internacionalização dos direitos humanos então, as nações recém-redemocratizadas passaram a incluir em seu rol de direitos os direitos fundamentais do homem, como foi o caso do Brasil, quando a promulgação da Constituição Federal de 1988.

No Brasil, a prisão, antes de sua implementação como poder punitivo do Estado, teve atribuições variadas, já foi hospício, alojamento de escravos e ex-escravos, foi asilo para menores e fortaleza para conter adversários políticos. Foi em 1769, na Carta Régia do Brasil, que se determinou a construção da primeira prisão brasileira, no Rio de Janeiro, chamada de Casa de Correção ${ }^{24}$.

Durante o período colonial o Brasil recebeu o status de prisão de degredados, de um território de cumprimento de pena, situação que se estendeu até 1808 , mesmo ano que a família real portuguesa se mudara para território brasileiro ${ }^{25}$.

Até o momento, no rol de direitos previstos, nada constava sobre direitos fundamentais, sobre como deveriam funcionar os presídios e como deveria ser o tratamento das autoridades para com os apenados. Porém o contexto se alterou em 1824, com primeira constituição outorgada por Dom Pedro II, em que se determinou que os presídios separassem os réus de acordo com a pena e com o crime cometido bem como houvesse lugar para que os presos trabalhassem; nesta Carta Magna também se estabeleceu o primeiro rol de direitos fundamentais no Brasil, novidade no momento ${ }^{26}$.

A pena tem como finalidade principal regulamentar a convivência dos indivíduos em sociedade. Assim diz Cezar Roberto Bitencourt:

\footnotetext{
${ }^{24}$ PEDROSO, Regina Célia. Utopias penitenciárias projetos jurídicos e realidade carcerária no Brasil. Revista de História, n. 136, p. 121-137, 1997. p. 122.

${ }^{25}$ Ibidem.

${ }^{26}$ Ibidem. p. 123.
} 
Destacamos a utilização que o Estado faz do direito penal, isto é, da pena, para facilitar e regulamentar a convivência dos homens em sociedade. Apesar de existirem outras formas de controle social [...] o Estado utiliza a pena para proteger de eventuais lesões determinados bens jurídicos, assim considerados em uma organização socioeconômica específica. Pena e Estado são conceitos intimamente ligados entre si. $\mathrm{O}$ desenvolvimento do Estado está intimamente ligado ao da pena ${ }^{27}$

Atualmente, vige a Constituição Federal de 1988, que estabeleceu, em seu Capítulo dos Direitos e Garantias Individuais, diversos princípios e regras que visam proteger o indivíduo do poder abusivo do Estado; entre estes, garantiu tratamento humano ao preso, em que sua dignidade humana (art $1^{\circ}$, inciso III, $\mathrm{CF} / 88$ ) e sua integridade física e moral são inteiramente respeitadas (artigo $5^{\circ}$, inciso XLIX, CF/88), ou seja, o preso conserva todos os seus direitos de cidadão que não são compatíveis com a liberdade de ir e vir (já que esta está cerceada enquanto ele cumpre a pena).

A vigente Carta Magna preza pela existência digna de todos os cidadãos, seu artigo 170, inclusive, explicita que "A ordem econômica, fundada na valorização do trabalho humano e na livre iniciativa, tem por fim assegurar a todos existência digna”.

No mesmo artigo $5^{\circ}$, agora no inciso XLVII, da Constituição Federal, vê-se que não são permitidas no ordenamento brasileiro as penas de morte, de trabalho forçado, de banimento, a prisão perpétua, ou ainda penas cruéis (como a tortura). A CF/88 também proíbe a pena de trabalhos forçados, pois seu cerne democrático estabelece a capacidade de autodeterminação do indivíduo em relação ao exercício ou não de atividade laboral.

A $\mathrm{CF} / 88$ também prevê direitos a serem observados no âmbito processual, como, por exemplo, o inciso LXII do artigo $5^{\circ}$ que versa que "a prisão de qualquer pessoa e o local onde se encontre serão comunicados imediatamente ao juiz competente e à família do preso ou à pessoa por ele indicada", o inciso LXIII, do mesmo artigo, que diz que "o preso será informado de seus direitos, entre os quais o de permanecer calado, sendolhe assegurada a assistência da família e de advogado"; o inciso seguinte LXIV - também trata do tema, dizendo que "o preso terá direito à

${ }^{27}$ BITENCOURT, Cezar Roberto. Falência da Pena de Prisão: Causas e alternativas. 3. ed. São Paulo: Saraiva, 2004. p. 103. 
identificação dos responsáveis por sua prisão ou por seu interrogatório policial", além de muitos outros (art. $5^{\circ}, \mathrm{LXV}$, etc.).

A não observância destes direitos processuais culmina no surgimento de outros direitos para o preso, garantia constitucional também característica de países democráticos, que é a possibilidade de impetrar habeas corpus (remédio processual previsto no artigo $5^{\circ}$, inciso LXVIII, $\mathrm{CF} / 88$ : "conceder-se-á habeas corpus sempre que alguém sofrer ou se achar ameaçado de sofrer violência ou coação em sua liberdade de locomoção, por ilegalidade ou abuso de poder").

\subsection{CÓDIGO PENAL E DE PROCESSO PENAL BRASILEIRO}

A Constituição Federal de 1988 já enumera os bens protegidos que ensejam em prisão caso desrespeitados (como a vida, liberdade, privacidade, entre outros), e a Lei 12.403/2011 pôs a prisão, prevista no Código Penal, em status de ultima ratio no ordenamento, ou seja, apenas utilizada quando de extrema necessidade, em que não há outras maneiras de resolução do conflito. Assim versou sobre a referida lei a doutrinadora Maria Thereza Rocha de Assis Moura:

Com a reforma, a liberdade, antes do trânsito em julgado da sentença condenatória, é a regra, nos termos do que dispõe, desde 1988, a Constituição da República (art. $5^{\circ}$, inciso LXVI), e a prisão, a exceção. Isto signifi ca que a prisão preventiva tem caráter de subsidiariedade, somente sendo admitida quando não for cabível a sua substituição por outra medida cautelar (art. $\left.282, \S 6^{\circ}\right)^{28}$

Entre os principais princípios constitucionais que se referem à execução da pena, citar-se-ão os da personalidade, individualização e humanidade da pena.

O primeiro consta no supracitado Capítulo dos Direitos e Garantias Individuais da Constituição, mais precisamente no artigo $5^{\circ}$, inciso XLV, diz sobre a intranscendência da pena, significa que ninguém, além do condenado, pode ser punido pelos crimes cometidos, nem familiares nem cônjuges, ou seja, a imposição da pena dependeria da culpabilidade do autor do delito. Sobre ele esclareceu o Supremo Tribunal Federal:

\footnotetext{
${ }^{28}$ DE ASSIS MOURA, Maria Thereza Rocha. A Nova sistemática das medidas cautelares pessoais no processo penal brasileiro. SUPERIOR TRIBUNAL DE JUSTIÇA, p. 139, 2014. p. 143.
} 
O Supremo Tribunal Federal também coloca a culpabilidade do agente como medida da aplicação da pena e destaca que a individualização da pena, que deve ser motivada, é um direito público subjetivo do apenado (HC 72992/SP-963) ${ }^{29}$.

O segundo princípio, o da individualização da pena, é um importante marco no direito penal, visto que as penas passaram a se classificar de acordo com as características e singularidades de cada criminoso. Este princípio encontra-se materializado no art. 11 do Código Penal, que prevê que "o resultado, de que depende a existência do crime, somente é imputável a quem lhe deu causa" e também, em seu artigo 59, o qual diz in verbis:

Art. 59 - O juiz, atendendo à culpabilidade, aos antecedentes, à conduta social, à personalidade do agente, aos motivos, às circunstâncias e conseqüências do crime, bem como ao comportamento da vítima, estabelecerá, conforme seja necessário e suficiente para reprovação e prevenção do crime:

I - as penas aplicáveis dentre as cominadas;

II - a quantidade de pena aplicável, dentro dos limites previstos;

III - o regime inicial de cumprimento da pena privativa de liberdade;

IV - a substituição da pena privativa da liberdade aplicada, por outra espécie de pena, se cabível. ${ }^{30}$

O terceiro princípio, o da humanidade da pena, trata-se de uma racionalização justa da pena que veio para a concretização do Princípio da Dignidade Humana. Veja as palavras de André Del Grossi Assumpção sobre o ele:

Pondera-se que a sustentação da humanidade das penas é mais antiga e contemporânea do processo de afirmação da Legalidade como parâmetro de atuação do poder estatal quando da intervenção na liberdade do indivíduo, ao passo que a noção de Dignidade da Pessoa Humana é mais recente mas, acrescentando um novo horizonte às proposições de cunho racional e utilitarista, terminou por se estabelecer como a base principal do próprio Estado de Direito $^{31}$

\footnotetext{
${ }^{29}$ SUPREMO TRIBUNAL FEDERAL. 1a Turma. HC 72.992/96. Rel. Min. Celso de Mello. v.u. DJ de 14.11.96.

${ }^{30}$ BRASIL. Código de Processo Penal. Decreto lei $n^{\circ} 3.689$, de 03 de outubro de 1941. Disponível em: <http://www.planalto.gov.br/ccivil_03/decreto-lei/del3689.htm>. Acesso em: 15 ago 2019.

${ }^{31}$ ASSUMPÇÃO, André Del Grossi. A humanidade das penas e a dignidade da pessoa humana em perspectiva da fuga de preso. Revista do Direito Público, v. 5, n. 1, p. 73.
} 
O princípio da humanidade da pena nada mais é que o resultado ou a conjugação do cumprimento dos princípios anteriores.

A pena de prisão está prevista no artigo 32 do Código Penal, descrita com especificidades e critérios que disciplinam sua aplicação.

Ao iniciar o cumprimento de sua pena, o apenado possui, também, direitos e deveres, além de determinados benefícios, de acordo com seu mérito, que influenciam na execução penal e na sua futura ressocialização.

Podemos citar como alguns desses benefícios a progressão de regime, a detração da pena e a remição da pena.

O primeiro trata da progressão de um regime mais rigoroso para um menos rigoroso desde que o detento cumpra os critérios subjetivos (bom comportamento) e objetivos (determinado tempo de cumprimento de pena, variável de acordo com a tipicidade do crime - crime comum, hediondo).

O objetivo da progressão de regime é incentivar o preso à se responsabilizar pela amenização de sua própria pena, segundo Carlos Augusto Borges:

Umbilicalmente ligada à própria pena, a progressividade do regime acena ao condenado com melhores dias, incentiva-o à correção de rumo e, portanto, a empreender um comportamento penitenciário voltado à ordem, ao mérito e a futura inserção no meio social e familiar e da vida normal que tem direito um ser humano. Somente com a progressão de regime o preso poderá freqüentar cursos profissionalizantes, de instrução de segundo grau ou superior, exercer atividade laborativa não disponibilizada pelo Estado, e estar próximo do ambiente familiar, nos casos de trabalho extra-muros e de visitação temporária ao $\operatorname{lar}^{32}$.

A detração da pena está prevista no artigo 42 do Código Penal, que diz que "computam-se, na pena privativa de liberdade e na medida de segurança, o tempo de prisão provisória, no Brasil ou no estrangeiro (...)", ou seja, o tempo em que o apenado passou aguardando em prisão a sentença condenatória ou cumprindo medida de segurança, será descontado do tempo final proferido na sentença.

\footnotetext{
${ }^{32}$ BORGES, Carlos Augusto. O sistema progressivo na execução da pena e a realidade carcerária. 2008. Disponível em: <http://www.tjrj.jus.br/institucional/vep/sistema_prog_penas.pdf. Acesso em: 08 set. 2019.
} 
Passando, agora, ao estudo sobre o Código de Processo Penal, vêse que, segundo Aury Lopes Jr e Caio Paiva ${ }^{33}$, o processo penal é o ramo do direito que mais "sofre" (mais se beneficia) com a normativa dos Tratados Internacionais de Direitos Humanos, não sendo exagero se falar que para se alcançar o devido processo, atualmente, ele não deve ser apenas legal e constitucional, mas convencional, ou seja, deve ter seus danos analisados a partir da perspectiva dos direitos humanos para que surja, talvez, uma nova política criminal orientada a reduzi-los.

$\mathrm{O}$ rol de medidas cautelares no CPP foi reformulado e aumentado pela Lei n. 12.403 de 2011, acrescentando nele medidas cautelares diferentes da prisão para assegurar a ordem processual, visto que, anteriormente, o magistrado não dispunha de meios para tal a não ser a prisão preventiva. Segundo BOTTINI, lê-se:

\begin{abstract}
A redação anterior do Código apresentava ao magistrado uma medíocre dicotomia no campo das cautelares pessoais. O juiz não dispunha de alternativa para assegurar a ordem processual e a aplicação da lei penal a não ser a prisão preventiva. Era a prisão ou nada. (...) A nova redação do Código apresenta uma gama de medidas cautelares pessoais diferentes da prisão para assegurar a ordem processual. $(. . .)^{34}$
\end{abstract}

A superação dessa medíocre dicotomia, segundo o autor, protege de maneira mais efetiva o processo, o acusado e a própria sociedade: $\mathrm{o}$ processo, pois surgiu um novo rol apto ao resguardo da ordem; o acusado, pois a prisão cautelar será a última opção e a sociedade, pois a redução da prisão cautelar significa o desencarceramento de cidadãos sem condenação definitiva, pondo em liberdade os que ainda aguardavam por seu julgamento, ou seja, livrando-os desta "cultura de prisão".35

Assim, o processo penal deu mais um passo de contribuição para um processo justo, eficaz e humanizado, angariando embasamento para que todos vejam seus direitos e dignidade respeitados assim como todos os princípios decorrentes deles.

\title{
3.4 A LEI DE EXECUÇÃO PENAL
}

\footnotetext{
${ }^{33}$ LOPES JR, Aury; PAIVA, Caio. Audiência de custódia e a imediata apresentação do preso ao juiz: rumo à evolução civilizatória do processo penal. Revista Liberdades, n. 17, 2014, p. 164-165.

${ }^{34}$ Idem.

${ }^{35}$ Idem.
} 
Ao passo que o Direito Penal é a última via para a resolução de conflitos na sociedade, a Lei de Execução Penal (Lei n. 7.210/1984) visa garantir a efetividade da punição do indivíduo já recluso. Segundo Cláudio do Prado Amaral:

$\mathrm{Na}$ fase de execução da pena privativa de liberdade, deve ser realizada delicada tarefa, que consiste em cumprir a sentença penal condenatória e, ao mesmo tempo, sobretudo observar o fim de prevenção especial positiva ou de ressocialização ${ }^{36}$

Quando a Lei propõe, em seu primeiro artigo, "proporcionar condições para a harmônica integração social do condenado" ${ }^{37}$ não se afasta do ideal de ressocialização presente no sistema penal em si, inclusive, esta lei, segundo Cláudio do Prado Amaral deve ser interpretada segundo a $\mathrm{CADH}^{38}$. Inspirada nas Regras Mínimas de Tratamento de Prisioneiros da ONU, extrai-se que o que o legislador buscava com sua instituição era a harmonia social e a recuperação daqueles que, por algum motivo, se desviaram dos padrões adotados pela sociedade.

A Lei materializa princípios constitucionais e, assim como a $\mathrm{CF} / 88$, estabelece a humanização da pena e tratamentos dignos aos cidadãos presos, que, juntamente com o Estado e através do cumprimento de direitos e deveres, resultaria na recuperação destes e sua reinserção na vida em sociedade. A CF/88 fixa direitos que asseguram a integridade física e moral do preso, a LEP vem, então, para estabelecer outros direitos, como o trabalho remunerado, a separação dos presos de acordo com suas personalidades, a assistência social, saúde (atendimento médico e farmacêutico), higiene, visitas, educação, entre outros.

A Lei de Execução Penal não só preza pela observância de certas regras dentro da gerência dos presídios, mas traz o juiz de direito para dentro da execução da pena, incentivando-os a fazerem o uso de penas alternativas (como fiança, prestação de sérvios, suspensão condicional da pena, etc.), a zelarem pelo devido processo legal, a fiscalizarem os

\footnotetext{
${ }^{36}$ DO PRADO AMARAL, Cláudio. Um novo método para a execução da pena privativa de liberdade. Revista de Informação Legislativo, v. 53, n. 209, 2016. p. 63 ,

${ }^{37}$ BRASIL. Lei $N^{o} 7.210$, de 11 de Julho de 1984. Institui a Lei de Execução Penal. Brasília, 11 de julho de 1984; $163^{\circ}$ da Independência e $96^{\circ}$ da República. Disponível em: < http://www.planalto.gov.br/ccivil_03/leis/L7210.htm>. Acesso em: 29/08/2019

${ }^{38}$ Ibidem. DO PRADO AMARAL, Cláudio. ... p. 60.
} 
incidentes de execução (progressão ou regressão do regime de pena), entre outras coisas. $^{39}$

Portanto, vê-se que a LEP considera que a ressocialização do apenado ocorre em âmbito penitenciário e preza pela observância dos já consagrados Direitos Humanos e dos princípios constitucionais e infraconstitucionais.

\section{REALIDADE: "O ESTADO DE COISAS INCONSTITUCIONAL"}

Nota-se, então, que ao sistema brasileiro não faltam disposições e amparos legais para o sustento da funcionalidade dos presídios e manutenção de todos os direitos dos que os adentram. Entretanto, na realidade fática, o que se nota é um intenso desrespeito às determinações legais, resultado do descaso de autoridades ou, até, da falta de recursos para melhoria efetiva da situação.

Verdadeiramente, o momento histórico brasileiro é de grande preocupação com a segurança pública, entretanto, embora pertinente, esta demasiada preocupação regrediu o entendimento que já estava solidificado sobre controle estatal, levando o Brasil a seguir a tendência mundial da modernidade, que, paradoxalmente, está marcada como um período de retrocessos e que Garland duramente criticou dizendo que, o que anteriormente eram processos de civilização e racionalização, agora, "engatava a marcha ré”:

\footnotetext{
39 JÚNIOR, Roberto Delmanto. 25 anos de Lei de execução Penal. Boletim 201. Agosto/2009. Disponível em: <https://www.ibccrim.org.br/boletim_artigo/3921-25-anos-de-Lei-de-ExecucaoPenal>. Acesso em: 12/08/2019.
} 
(...) desenvolvimentos recentes em controle de crimes e justiça criminal são intrigantes porque parecem envolver uma repentina e surpreendente reversão de padrões históricos estabelecidos. Eles exibem uma nítida descontinuidade que exige ser explicada. Os processos modernizadores que, até recentemente, parecia tão bem estabelecido nesse campo - acima de todas as tendências de longo prazo em direção à 'racionalização' e 'civilização' - agora parecem terem engatado a "marcha-ré". O reaparecimento, na política oficial, de sentimentos punitivos e gestos expressivos que parecem estranhamente arcaicos e, francamente, antimodernos, tende a confundir as teorias sociais de punição padrão e seus desenvolvimentos históricos. Nem mesmo a leitura mais inventiva de Foucault, Marx, Durkheim e Elias sobre a punição poderiam ter previsto esses desenvolvimentos recentes -e certamente nenhuma dessas previsões jamais apareceram. ${ }^{40}$

Ou seja, de acordo com Garland, há uma reaparição dos sentimentos punitivos arcaicos que contrariam e confundem parte considerável e consolidada dos estudos já feitos nas ciências sociais e sociais sobre o problema criminal e punitivo, bem como seus desenvolvimentos.

Neste contexto, o fenômeno securitário brasileiro mostra-se cada vez mais autoritário e seletivo, culminando em um aumento descomunal de penas, de presos, de violações à garantias e direitos, entre outras consequências mais severas.

Além das claras consequências sociais que o recrudescimento securitário causou no país, há os problemas estruturais de cada presídio brasileiro, presídios que não foram construídos para acolher o número atual de pessoas e que deixam o cidadão-preso à mercê de sua própria sorte, haja vista que são impossibilitados de dormirem - e se alimentarem com dignidade, vivendo sem higiene, sem assistência médica, ou seja, todos os direitos a eles sedimentados por Lei e por tratados internacionais foram esquecidos -, existindo, na realidade, uma situação de exceção e esquecimento destas pessoas.

\footnotetext{
40 (Livre tradução do trecho: "recent developments in crime control and criminal justice are puzzling because they appear to involve a sudden and startling reversal of the settled historical pattern. They display a sharp discontinuity that demands to be explained. The modernizing processes that, until recently, seemed so well established in this realm - above all the long-term tendencies towards 'rationalization' and 'civilization' - now look as if they have been thrown into reverse. The re-appearance in official policy of punitive sentiments and expressive gestures that appear oddly archaic and downright antimodern tend to confound the standard social theories of punishment and its historical development. Not even the most inventive reading of Foucault, Marx, Durkheim, and Elias on punishment could have predicted these recent developments - and certainly no such predictions ever appeared") GARLAND, David. The Culture of Control: Crime and Social Order in Contemporary Society. Chicago: The University Of Chicago Press, 2001. p. 3.
} 
O Código Penal ${ }^{41}$, como já visto, estabeleceu que no Brasil haveria 3 tipos de regimes que dividiriam os presos condenados: os fechados (presídios), os semi-abertos (colônias agrícolas e industriais) e os abertos (casas de albergado); entretanto, um estudo realizado pela Human's Right Watch informou que a realidade brasileira passa longe do que estabelece a Lei, principalmente porque falta infraestrutura que garanta o cumprimento dela. Por exemplo, existem apenas 64 casas de albergado em território nacional, o que nos leva a pensar que, de fato, o regime aberto não é levado a sério no Brasil e os presos em regime aberto passam anos cumprindo suas penas em delegacias.

A grave superlotação nos presídios brasileiros seja talvez o mais crônico problema que aflige o sistema penal. O supracitado levantamento feito pelo INFOPEN demonstrou que há um déficit de 358.663 vagas nos presídios, ou seja, há vaga para apenas 368.049 dos 726.712 presos no Brasi $^{42}$.

A superlotação não reflete apenas na acomodação subumana dos presos, mas também, dificulta a manutenção da higiene, facilitando e aumentando a disseminação de doenças, impossibilita o sono do condenado, além da dificuldade, por parte dos policiais, em manter a ordem - o que gera um aumento da violência entre os presos e entre policiais e presos - e, por fim, torna o objetivo de ressocialização do indivíduo inalcançável.

Parte da crise consta, também, do fato de os presídios brasileiros não serem estruturados fisicamente e assistencialmente, não há atendimento médico eficiente, pois não há consultórios suficientes, a iluminação e ventilação são prejudicadas (e, consequentemente, a umidade do ar é elevada, facilitando a proliferação de fungos e mofo), os pátios são excessivamente lotados de presos, entre outros problemas. Portanto, há deficiência na estrutura física e material que afeta a humanidade dos presos, e, aparentemente, perdem sua cidadania ao adentrarem nos presídios brasileiros.

Importante ressaltar, também, a seletividade do sistema, que prende preferencialmente cidadãos de cor de pele negra, entre 18 e 24 anos e de baixa escolaridade. De acordo com a pesquisa realizada pelo INFOPEN (já citada anteriormente), 64\% das pessoas aprisionadas são

\footnotetext{
${ }^{41}$ O Código Penal estabeleceu e a LEP, posteriormente, detalhou condições de cumprimento da pena dentro das instituições incumbidas para tanto.

${ }^{42}$ Cf. item 15 ..
} 
negras, $51 \%$ não terminaram o ensino fundamental, $28 \%$ se relacionam com o crime de tráfico e $37 \%$ de roubo ${ }^{43}$.

O que se nota, assim, no Judiciário, independentemente de quem cometeu o crime ou não, é que há uma situação de vigilância racial, em que os agentes segurança pública buscam indivíduos que se encaixam na estatística para ocuparem o "banco do réu".

Fica evidente, então, a seletividade do Direito Penal brasileiro, que escolheu como inimigos os negros e pobres e cerceia suas liberdades quando cometem crimes ou quando apenas são "confundidos ou comparados com bandidos".

Além de todos os problemas supracitados, é mister que se analise, ainda que não afundo, a situação das mulheres brasileiras privadas de liberdade.

A discriminação de tratamento devido à diferença de gênero ocorre quando, por exemplo, se prioriza a construção de unidades prisionais para a população masculina enquanto a população feminina é encarcerada em presídios masculinos, mistos ou em cadeias públicas. A maioria das penitenciárias brasileiras foi projetada para acolher homens privados de liberdade e, posteriormente, adaptada ao acolhimento também de mulheres. ${ }^{44}$

As normas penais e sua execução foram estruturadas a partir do ideal masculino de delinquência, assim, questões de gênero, como a gravidez, a amamentação e a própria infraestrutura fazem com que a mulher encarcerada seja duplamente prisioneira: por ser mulher e por ser criminosa $^{45}$. O tratamento desumano e degradante, a falta de especificidade às peculiaridades da mulher em situação de privação de liberdade e as condições do sistema penal fazem com que a possibilidade de ressocialização seja mais difícil do que aparenta ser para a mulher encarcerada.

Outro problema visceral que assombra o sistema penitenciário brasileiro é a prisão provisória. Não se questiona, aqui, sua constitucionalidade ou sua característica de cautelaridade em si, mas a sua difusão como prima ratio na execução penal. Embora a lei e a doutrina disciplinem sua excepcionalidade, não é o que acontece no Brasil.

\footnotetext{
${ }^{43}$ Ibidem.

${ }^{44}$ Ibidem. p. 15-16.

${ }^{45}$ LOPES, Rosalice. Prisioneiras de uma mesma história: o amor materno atrás das grades. Tese (doutorado em psicologia) Universidade de São Paulo, São Paulo, 2004. p. 18
} 
Até junho de $2016^{46}$, $41 \%$ das pessoas presas no Brasil ainda não haviam sido julgadas ou condenadas, ou seja, em prisão provisória.

Segundo normas dos direitos humanos, ou até preceitos constitucionais, parcialmente estudados no segundo capítulo deste trabalho, ninguém é culpado até trânsito em julgado da sentença penal condenatória, devendo o acusado se manter em liberdade enquanto seu julgamento está pendente. Isto no Brasil não ocorre.

A "popularização" da prisão provisória agrava não só o problema da superlotação de presídios, mas a própria ressocialização do preso. Suponha-se que um indivíduo inocente aguardou meses preso aguardando um julgamento que, posteriormente, o considerará inocente; as chances de ele retomar sua vida sem este estigma são mínimas.

Por fim, não bastasse todos os problemas enfrentados pelo direito penal no Brasil, observa-se seu problema mais visceral, qual seja, a total falha no alcance de um dos principais objetivos da pena: a ressocialização do preso.

Há os que atribuem esta falha à duração da pena e à capacidade de adaptação do seu humano, como Leonardo Yarochewsky, que diz:

\footnotetext{
Quanto mais duradoura for a pena privativa de liberdade maiores serão suas contradições e mais distante estará o preso de uma adaptação à vida fora da prisão. Por mais incrível que possa parecer, aquele que ficou preso durante anos acaba se incorporando a \"sociedade prisionall", isto porque dentro das prisões existem outros costumes, outra linguagem, outros \"códigosl", outras ।"leis\" passam a vigorar, as quais são impostas pelo perverso sistema penitenciário. ${ }^{47}$
}

O que se nota é que não há exatamente como pontuar o que, especificamente, é a causa desta situação, senão a soma de várias infrações às diretrizes estabelecidas anteriormente sobre como administrar o presídio e como lidar com os que têm sua liberdade privada.

Há ainda o preconceito em torno dos ex-presidiários no Brasil, o que dificulta seu reingresso ao mercado de trabalho e social e, como consequência, sua ressocialização. Sandro Dias e Lourival José de Oliveira bem pontuaram:

\footnotetext{
${ }^{46}$ Ibidem. item 15.

${ }^{47}$ YAROCHEWSKY, Leonardo. Ressocialização, reintegração, reeducação ou recuperação do condenado: uma grande farsa. São Paulo, 20 jun 2005. Disponível em: <www.ibccrim.org.br〉, Acesso em: 20 ago 2019.
} 
Do lado de fora dos presídios, os ex-presidiários não encontram condições favoráveis para ingresso no mercado de trabalho, pois carregam a marca do estigma social negativo de ser um ex-preso. O preconceito em relação a ser um ex-presidiário é uma forma de punição invisível que carregará durante a vida toda. Há várias restrições legais que diminuem as chances de um ex-presidiário encontrar emprego ${ }^{48}$.

Além do descaso com as próprias vidas dos presos, na conjuntura brasileira ainda pode-se observar outro crescente e assombroso problema: o domínio, cada vez maior, de grupos criminosos.

Os grupos criminosos surgiram, a princípio, como uma organização dos próprios presos para se protegerem dos abusos do Estado, posteriormente, tornaram-se uma forma de extorsão entre os presos para que possuíssem o mínimo necessário para sua sobrevivência e integridade física. $^{49}$

O surgimento destes grupos é produto dos fatores já citados, anteriormente, no presente trabalho, como o pouco investimento na administração dos presídios e o descaso com as necessidades dos presos (necessidades básicas como higiene, alimentação e segurança). Assim Sérgio Adorno explicitou:

A despeito dos investimentos em segurança pública, ora crescentes ora decrescentes, sobretudo em recursos materiais, são notórias as dificuldades e desafios enfrentados pelo poder público em suas tarefas constitucionais de deter o monopólio estatal da violência, mesmo após quase duas décadas de retorno ao Estado democrático de Direito. Seus sintomas contemporâneos radicam, por exemplo, na sucessão de rebeliões nas prisões organizadas por dirigentes do crime organizado, como o Comando Vermelho e Terceiro Comando, no Rio de Janeiro; e o Primeiro Comando da Capital, em São Paulo, este responsável pelo motim simultâneo de vinte e nove grandes prisões, no Estado de São Paulo, em fevereiro de 2001. Do mesmo modo, cada vez mais é flagrante a ousadia no resgate de presos. Ademais, a existência de áreas, na maioria das metrópoles brasileiras, onde prevalecem as regras ditadas pelo tráfico de drogas sugere a constituição de quistos urbanos isentos da aplicação das leis. ${ }^{50}$

48 DIAS, Sandro; DE OLIVEIRA, Lourival José. A Reinserção Social Através do Trabalho: Responsabilidade Empresarial no Resgate da Dignidade da Pessoa Humana. Revista Jurídica CesumarMestrado, v. 14, n. 1, 2014. p. 151.

${ }^{49}$ SILVEIRA, VALDIR JOÃO. A realidade dos presídios na visão da Pastoral Carcerária. estudos avançados, v. 21, n. 61, p. 209, 2007. Disponível em: <http://www.scielo.br/scielo.php?pid=S010340142007000300014\&script=sci_arttext\&tlng=pt > Acesso em: 08 set. 2019.

${ }^{50} \mathrm{Cf}$. item 66. 
Assim, as autoridades Estatais responsáveis pelos presídios brasileiros encontram-se de "mãos atadas" frente ao combate à criminalidade e à formação de facções criminosas, que só diminuirão quando alguma política efetivamente cobrir e sanar as lacunas deixadas pela administração dos presídios no trato com os condenados.

\subsection{O DEBATE NO STF: O SISTEMA PENITENCIÁRIO BRASILEIRO COMO “ESTADO INCONSTITUCIONAL DE COISAS"}

Diante da preocupante situação que o sistema penitenciário se encontra e do cruel e desumano tratamento que se dá aos presos no Brasil, o Partido Socialista Brasileiro, em 2016, ingressou com uma Arguição de Descumprimento de Preceito Fundamental, autuada sob o número 347.

Importante ressaltar, então, o teor da ADPF supracitada e conceituação dada ao "estado inconstitucional de coisas":

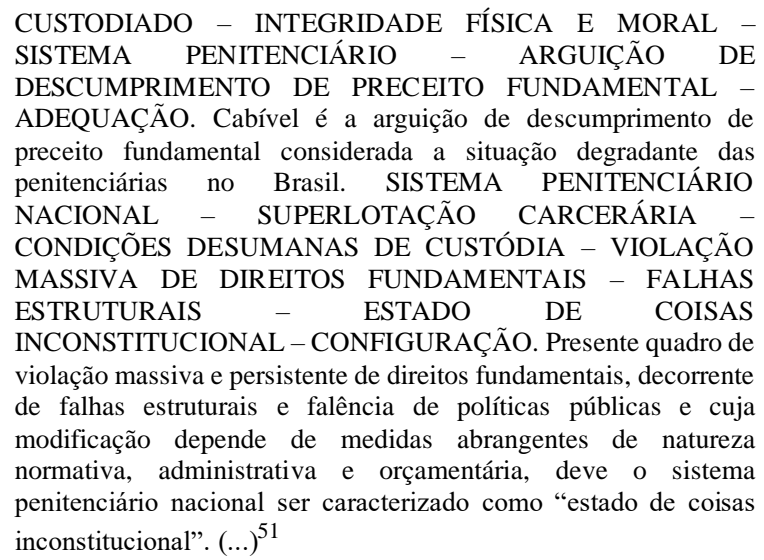

Além do reconhecimento do EIC, a ADPF requereu da União que houvesse um plano para a superação problemática das penitenciárias com

\footnotetext{
${ }^{51}$ BRASIL. Supremo Tribunal Federal. Tribunal Pleno. Medida Cautelar na Arguição de Descumprimento de Preceito Fundamental $\mathrm{n}^{\circ}$ 347. Requerente: Partido Socialismo e Liberdade. Requeridos: União et al. Relator: Min. Marco Aurélio. Brasília, 09 set. 2015. Diário da Justiça Eletrônico, n. $\quad 31, \quad 19$ fev. 2016. Disponível em: $<$ http://stf.jus.br/portal/inteiroTeor/obterInteiroTeor.asp?idDocumento=10300665>. Acesso em 08 set. 2019.
} 
metas mais específicas, como o diálogo entre os Poderes, a melhora da estrutura dos presídios e redução da superlotação através da redução de presos provisórios, visto que a liberdade é direito protegido pelo Tratado Internacional dos Direitos Humanos e a prisão deveria ser, desde sempre, ultima ratio na resolução de problemas.

Dentre as principais decisões deferidas, cabe ressaltar a que solicita que mais audiências de custódia sejam realizadas e que os presos fossem apresentados à autoridades em até $24 \mathrm{~h}$ após a prisão em flagrante, segundo o Ministro Ricardo Lewandowski, esta medida deixaria de prender mais de 120 mil indivíduos e geraria uma enorme economia para o erário além de amenizar o problema da superlotação. Por fim, o STF aderiu à determinação de que a União liberasse o saldo acumulado do Fundo Penitenciário Nacional (FUNPEN) para utilização adequada ao que fora destinado e se abstivesse de realizar novos contingenciamentos, sendo acrescido, ainda, pelo Ministro Luis Roberto Barroso, um prazo para que a Administração Pública Federal apresente um diagnóstico do sistema prisional - esta de mister importância visto que notou-se verbas encaminhadas ao sistema prisional que não estavam sendo aplicadas para a sua melhora ${ }^{52}$.

Inegavelmente, é um grande avanço para a legislação brasileira, entretanto, ainda depende de aperfeiçoamento, visto que ainda não se pode calcular sua abrangência federal.

Em que pese a importância deste instituto, as fundamentações de decisões baseadas nele, devem ser profundamente detalhadas pois, embora ele garanta a integridade física do apenado e seja essencial para o respeito de sua dignidade, ainda é visto com ativismo judicial em muitos casos.

O sucesso da implementação da Teoria do Estado Inconstitucional de Coisas depende da eficaz aplicação de políticas públicas de segurança, de forma adaptada a situação e necessidades de cada população carcerária e do diálogo entre os Poderes, ou, um diálogo institucional, envolvendo não só os Poderes como todos os órgãos responsáveis e envolvidos nos problemas prisionais, bem como com a sociedade civil, a fim de desenvolver possíveis alternativas para o grave problema institucional. 


\section{REDUÇÃO DE DANOS: LIMITES E POSSIBILIDADES DAS APACS NO GERENCIAMENTO DA QUESTÃO PENITENCIÁRIA NO BRASIL}

Como resposta aos problemas enfrentados pelas penitenciárias brasileiras, o trabalho passa agora a analisar a importância da difusão do modelo APAC como uma possível alternativa para a amenização da superlotação e auxílio para o alcance do objetivo substancial do Direito Penal brasileiro.

A sigla APAC significa "Associação de Proteção e Assistência aos Condenados", porém, surgiu sob o lema de cunho religioso "Amando ao Próximo Amarás a Cristo" 53 . Interessante frisar, pois, que o caráter espiritual cristão das APACs vem desde antes de sua idealização. A princípio, o projeto era de alguns voluntários que tinham como objetivo visitar mensalmente o presídio de São José dos Campos-SP para fins de evangelização dos apenados, posteriormente, com estudos e aprofundamento nos problemas da execução penal, foi criada a proposta de reintegração e reinserção dos condenados, focando em aspectos processuais e jurídicos da pena e sua execução, a partir da reconstituição da família e do trabalho honesto. Tudo, a bem da verdade, partindo de uma inicial visão espiritual e evangelística ${ }^{54}$.

Ao trabalhar com a população prisional que vivenciava constantes rebeliões advindas das más condições enfrentadas, a APAC possui um método diferenciado (que será aprofundado no decorrer do presente capítulo) e busca sua preparação para se reintegrar na sociedade através da reconstrução moral do preso, resultando na sua futura ressocialização ${ }^{55}$.

Seu principal mentor é o advogado Mário Ottoboni que comandou um grupo de 15 voluntários cristãos em 1972 em São José dos Campos/SP visando humanizar a pena de prisão e a valoração humana. Sua primeira oportunidade de testar o modelo APAC foi após uma revolta

\footnotetext{
${ }^{53}$ COUTINHO, Adriana de Souza Lima. Família, trabalho e religião: fatores de reintegração do detento? Um estudo comparativo e descritivo entre o sistema prisional comum e a Associação de Proteção e Assistência aos Condenados. 2009. Tese de Doutorado. Tese de Pós-Graduação.p. 35

${ }^{54}$ SILVA, Jane Ribeiro (org.). A execução penal à luz do método APAC. Belo Horizonte: Tribunal de Justiça do Estado de Minas Gerais, 2012. p. 26

${ }^{55} \mathrm{Cf}$. item 51. COUTINHO, ...
} 
ocorrida em um presídio de sua cidade, já que, devido a ela, um grupo de 15 presidiários ficou desabrigado, sendo mandado para suas instalações ${ }^{56}$. A APAC, então, é "uma entidade civil de direito privado, sem fins lucrativos, com patrimônio e personalidade jurídica próprios e tempo de duração indeterminado. Cada APAC é autônoma - jurídica, administrativa e financeiramente" ${ }^{, 57}$ e auxilia os Poderes Judiciário e Executivo na execução penal e na administração do cumprimento das penas privativas de liberdade nos regimes fechados, semi-abertos e abertos $^{58}$.

Junto à APAC foi criada a FBAC - Fraternidade Brasileira de Assistência aos Condenados - cujo objetivo é fiscalizar, congregar e orientar as APACs no Brasil e ao redor do mundo, zelando pela consolidação, unidade e uniformidade delas ${ }^{59}$.

O método busca integrar os três protagonistas da execução penal, quais sejam: o criminoso, a sociedade e a vítima ${ }^{60}$, ou seja, busca recuperar o preso (aqui chamados de "recuperandos"), proteger a sociedade e socorrer as vítimas.

A metodologia aplicada nas APACs para o cumprimento de pena privativa de liberdade exige obediência e disciplina, além de respeito a todos e a tudo o que se faz dentro de seus estabelecimentos.

Para que um preso no sistema comum ingresse numa Associação, deve atender a requisitos básicos. Quanto a eles, assim enumera Jane Ribeiro Silva:

\begin{abstract}
$1^{\circ}$ - O preso deve ter situação jurídica definida, ou seja, a APAC somente recebe presos para cumprimento de pena no CRS se já estiver condenado pela Justiça, ainda que haja sentença sem o trânsito em julgado.

$2^{\circ}$ - A família do recuperando deve manter residência e domicílio na comarca onde está localizada a APAC ou no caso de o crime ter sido cometido na comarca.
\end{abstract}

\footnotetext{
${ }^{56}$ DE ALMEIDA, Frankarles Genes et al. A importância do método de Associação e Proteção Aos Condenados (APAC) para o sistema prisional brasileiro. Revista Direito \& Dialogicidade, v. 3, n. 1, 2013. p. 5.

${ }^{57}$ FERREIRA, V., e OTTOBONI, M. Método APAC: Sistematização de processos. Belo Horizonte: Tribunal do Estado de Minas Gerais. (2016). p. 20. Disponível em: <https://bd.tjmg.jus.br/jspui/bitstream/tjmg/7821/1/APAC.pdf> Acesso em: 29 ago. 2019.

${ }^{58}$ CABRAL, Luisa Rocha; SILVA, Juliana Leite. O trabalho penitenciário e a ressocialização do preso no Brasil. Revista do centro acadêmico Afonso Pena, v. 13, n. 1, 2010. p. 178.

${ }^{59}$ Cf. item 52. SILVA, Jane Ribeiro (org.)... p. 76.

${ }^{60}$ FONSECA, Daniel Naiff da. Considerações críticas sobre o atual modelo ressocializador de execução penal. Disponível na internet: www.ibccrim.com.br, 15.06.2001.
} 
$3^{\circ}$ - O condenado necessita manifestar por escrito o seu desejo de cumprir pena na APAC, ao mesmo tempo em que afirma concordar com as normas da entidade.

$4^{\circ}$ - Os condenados há mais tempo (critério de antiguidade) devem ter preferência quando do surgimento de vaga na APAC. ${ }^{61}$

Destarte, evidencia-se que o êxito da APAC se deve não somente à sua rigidez, mas à cooperação do preso, de sua família, da comunidade $\mathrm{e}$ do Judiciário e o que se vê da Associação de Proteção e Assistência aos Condenados é que ela está arraigada ao que se esperava advir da Lei (principalmente da Lei de Execução Penal) àqueles que estão presos e se dirige à busca pela paz e conscientização social.

Os números relativos à APAC, os quais embasam a hipótese que põe este modelo como alternativa à crise enfrentada pelo sistema carcerário brasileiro, serão os próximos pontos de abordagem da pesquisa.

Devido ao tratamento humanizado dos presos e da forma com a qual eles se sentem parte integrantes da Associação e responsáveis não só pela sua ressocialização, bem como com a de seus colegas encarcerados, não há ocorrência de rebeliões em seus estabelecimentos, isso mostra uma pesquisa realizada pela Professora Vera Lúcia Travençolo Muniz e seu aluno Eli Queiroz Lisbôa, na APAC de Itaúna ${ }^{62}$.

A mesma pesquisa também concluiu que os níveis de reincidência no recinto de Itaúna, cuja metodologia apaqueana é vigente, são de $6,7 \%$, enquanto no presídio tradicional o número alcança os $80 \%{ }^{63}$.

Segundo a Professora Vera Lúcia Travençolo Muniz e seu aluno Eli Queiroz Lisbôa, este método é responsável, segundo o CNJ, por índices de reincidência criminal que variam de $8 \%$ e $15 \%$. Estes índices são muito positivos se comparados aos de prisões tradicionais, que perfazem mais de $70 \%{ }^{64}$.

O método também se destacou no Estado do Paraná, devido ao sucesso na ressocialização dos condenados, e assim divulgou a notícia do próprio Tribunal de Justiça do Estado:

"A ideia de implantar esse sistema é reorganizar e humanizar o sistema carcerário, cumprindo-se a sua verdadeira função social, que é a de melhorar pessoas e não de piorá-las, como muitas vezes

\footnotetext{
${ }^{61}$ Cf. item 52. SILVA, Jane Ribeiro (org.). ... p. 34.

${ }^{62}$ MUNIZ, Vera Lúcia Travençolo \& LISBÔA, Eli Queiroz. O Sistema Penitenciário: razões históricas, sociais e jurídicas da falência do sistema prisional brasileiro quando da ressocialização do preso. Relatório Final de Pesquisa do PIBC/CNPq - UFV. p. 62.

${ }^{63}$ Ibidem.

${ }^{64}$ FERREIRA, Viviane Gonçalves. Governança colaborativa na prática: uma análise das experiências nas APACs. 2015. Tese de Doutorado. p. 62.
} 
acontece", afirma o Supervisor do Grupo de Monitoramento e Fiscalização do Sistema Carcerário e de Medidas Socioeducativas (GMF/PR), Desembargador Ruy Muggiati. A execução da pena com baixos custos (um salário mínimo por recuperando) teve altos índices de ressocialização, segundo o último levantamento apresentado pelo GMF/PR. ${ }^{65}$.

o bem ao ser humano não é o único fator que traz atenção à APAC, há também os benefícios colhidos pelo Estado quando a aplicação do método em questão. Como consta na cartilha fornecida pelo Tribunal de Justiça de Minas Gerais (supremencionada):

Sua importância econômica, social e política, de vez que se trata de sistema prisional que funciona com no mínimo três vezes menos recursos financeiros, 99\% menos pessoal do serviço público, atendendo a igual demanda de sentenciados e com resultados em média setenta vezes melhor do que o sistema convencional ${ }^{66}$

As APACs também se prestam a trazer socorro e justiça às vítimas e seus familiares, inclusive, ao imporem o item 7 da lista de preceitos fundamentais abordados nas instalações apaqueanas, não só a família do apenado recebe auxílio, mas a da vítima também. Segundo a obra organizada pela Desembargadora Jane Ribeiro Silva, do Tribunal de Justiça de Minas Gerais:

Há os cursos de formação e valorização humana para os familiares dos recuperandos, a assistência espiritual, material e psicológica para as vítimas ou familiares das vítimas, em que se insere a proposta de restauração das famílias e, por conseguinte, dos laços com a sociedade ${ }^{67}$

A metodologia apaqueana comprova, então, que não basta apenas prender um indivíduo que recorreu ao crime sem tratar seu psicológico, sem mostrar-lhe responsabilidade, opondo-se ao seu exercício de direitos constituídos e deveres ou, sem tratá-los com o mínimo de humanidade.

O Estado ganha com economia, a sociedade com segurança e o ser humano com dignidade.

\footnotetext{
${ }^{65}$ TJPR - TRIBUNAL DE JUSTIÇA DO ESTADO DO PARANÁ. Método adotado no Paraná faz com que índice de ressocialização de presos salte de 14\% para 91\%. Paraná: TJPR, 2017. Disponível em: <https://www.tjpr.jus.br/destaques/-/asset_publisher/11KI/content/metodo-adotado-no-paranafaz-com-que-indice-de-ressocializacao-de-presos-salte-de-14-para-91-/18319?inheritRedirect=false>. Acesso em 01 set. 2019.

${ }^{66}$ Cf. item 52. SILVA, Jane Ribeiro (org.) ... p. 192-93.

${ }^{67}$ Cf. item 52. SILVA, Jane Ribeiro (org.) ... p. 100.
} 
O Método APAC sozinho pode não resolver todos os problemas sociais ao redor da criminalidade, mas se difundido, causará grande impacto na crise enfrentada pelo sistema carcerário brasileiro.

\section{CONCLUSÃO}

Percebe-se que há uma tendência política e econômica na sociedade moderna que culminou no que, atualmente, chamou-se de punitivismo neoliberal, em que se passou a objetivar uma maior presença de um Estado policial e menos intervencionista economicamente.

Este discurso neoliberal de punição gerou uma onda de proibicionismo exacerbado e perseguição de grupos minoritários, que, consequentemente, gerou um fenômeno que Garland chamou de mass imprisonment, que prendeu demasiadamente a parcela mais perseguida da sociedade, ocasionando quase que uma "criminalização da pobreza".

No Brasil, país marcado por uma sociedade repleta de disparidades sociais vertiginosas e pela desigualdade econômica, (que, combinadas, geram um aumento inexorável da violência), a insegurança gerada além de não contar com políticas de atenuação, é agravada pelo uso pela polícia das chamadas "forças de ordem", que normalizaram a violência letal, execuções sumárias e "desaparecimentos", gerando um clima de maior terror entre o povo, que banalizou a violência praticada pelo Estado.

Assim, com as alterações históricas a respeito do crime e de como puni-lo, instituiu-se as penas privativas de liberdade - ou prisões.

Para que não houvesse abusos por partes de autoridades, a prisão foi embasada em uma série de direitos e deveres, do Estado e dos presos, para que funcionasse corretamente e que o direito à liberdade fosse o único a ser cerceado dos cidadãos-presos, enquanto todos os outros fossem mantidos.

No Brasil, inspirado pela Declaração Universal dos Direito Humanos, pelas Regras de Tratamento Mínimo e por tratados internacionais, o ordenamento conta com a Constituição Federal repleta de direitos e garantias fundamentais, que alicerçou os Códigos Penal e de Processo Penal brasileiros, além da criação da Lei de Execução Penal (Lei n. 7.210/1984) para que as pessoas punidas pudessem ver garantidos seus direitos, cumprissem seus deveres e o sistema obtivesse sucesso na diminuição da criminalidade e aumento da ressocialização dos condenados. 
Todavia, observou-se a distância que a realidade brasileira se encontra da expectativa prevista em lei, já que, se seguidas, os presídios não estariam com problemas funcionais e alcançariam o alvo almejado, qual seja, a ressocialização.

Esta falha no sistema é o que provoca fugas, rebeliões, superlotação de celas e principalmente, o aumento da violência e insegurança social. A falha e desestrutura chegou a níveis alarmantes, a ponto do STF ter decretado o sistema penitenciário brasileiro como um "estado inconstitucional de coisas" no julgamento da ADPF 347, em 2016.

Este cenário de intensa violação dos direitos humanos dentro das cadeias muito reflete na falha do sistema como ressocializador dos indivíduos que cometeram crimes, isto se comprova devido ao aumento exponencial da violência cada década, ao aumento do número de rebeliões e fugas, às elevadas taxas de reincidências dos presídios e ao surgimento de facções criminosas dentro dos próprios presídios.

Nestas circunstâncias, Mário Ottoboni, após estudos e testes na penitenciária de São José dos Campos, em 1972, propôs um o novo modelo de prisão, que vai na contramão dos modelos presentes e seus números se mostram, até então, positivos quando comparados com os modelos tradicionais de aprisionamento, de forma que é inegável os benefícios sociais colhidos após a consolidação desta metodologia no Brasil. Esta metodologia recebeu o nome de Associação de Proteção e Assistência aos Condenados - APAC.

As APACs envolvem toda a comunidade na ressocialização do preso, respeitando sua capacidade de autodeterminação e sua dignidade, além de ser rentável aos cofres públicos devido ao fato de um preso custar $1 / 3$ do que custaria no sistema comum de aprisionamento.

Seu êxito se comprova ao não se registrarem nenhuma rebelião, baixos índices de fugas e menores índices ainda de reincidência.

Juntamente com a FBAC - Fraternidade Brasileira de Assistência aos Condenados - este método teve seu sucesso reconhecido e exportado para diversos países

As APACs demonstraram ser possível um sistema justo e triunfante se todos se envolverem na recuperação dos apenados e os tratarem com dignidade, respeito e amor.

\section{REFERÊNCIAS}


ASSUMPÇÃO, André Del Grossi. A humanidade das penas e a dignidade da pessoa humana em perspectiva da fuga de preso. Revista do Direito Público, v. 5, n. 1, p. 73.

BITENCOURT, Cezar Roberto. Falência da Pena de Prisão: Causas e alternativas. 3. ed. São Paulo: Saraiva, 2004.

BOLDT, Raphael; KROHLING, Aloísio. Direitos humanos, tolerância zero: paradoxos da violência punitiva no estado democrático de direito. Prisma Jurídico, v. 10, n. 1, p. 33-48, 2011.

BORGES, Carlos Augusto. O sistema progressivo na execução da pena e a realidade carcerária. 2008. Disponível em: <http://www.tjrj.jus.br/institucional/vep/sistema_prog_penas.pdf. Acesso em: 08 set. 2019.

BRASIL. Código de Processo Penal. Decreto lei no 3.689, de 03 de outubro de 1941. Disponível em: <http://www.planalto.gov.br/ccivil_03/decreto-lei/del3689.htm>. Acesso em: 15 ago 2019.

BRASIL. Lei № 7.210, de 11 de Julho de 1984. Institui a Lei de Execução Penal. Brasília, 11 de julho de $1984 ; 163^{\circ}$ da Independência e $96^{\circ}$ da República. Disponível em: < http://www.planalto.gov.br/ccivil_03/leis/L7210.htm>. Acesso em: 29/08/2019

BRASIL. Supremo Tribunal Federal. Tribunal Pleno. Medida Cautelar na Arguição de Descumprimento de Preceito Fundamental $n^{\circ} 347$. Requerente: Partido Socialismo e Liberdade. Requeridos: União et al. Relator: Min. Marco Aurélio. Brasília, 09 set. 2015. Diário da Justiça Eletrônico, n. 31, 19 fev. 2016. Disponível em: <http://stf.jus.br/portal/inteiroTeor/obterInteiroTeor.asp?idDocumento=10300665>. Acesso em 08 set. 2019.

CABRAL, Luisa Rocha; SILVA, Juliana Leite. O trabalho penitenciário e a ressocialização do preso no Brasil. Revista do centro acadêmico Afonso Pena, v. 13, n. 1, 2010. p. 178.

CHOUKR, Fauzi Hassan. A Influência da Convenção Americana de Direitos Humanos no processo penal brasileiro. Boletim Científico-Escola Superior do Ministério Público da União. Brasília: ESMPU, Ano I, n. 4, p. 111-128, 2002.

COUTINHO, Adriana de Souza Lima. Família, trabalho e religião: fatores de reintegração do detento? Um estudo comparativo e descritivo entre o sistema prisional comum e a Associação de Proteção e Assistência aos Condenados. 2009. Tese de Doutorado. Tese de Pós-Graduação.

DAVID, Décio Franco; MACCOPPI, Jaqueline Alexandra. Punitivismo pós-moderno: hipertrofia penal e fetiche punitivo pela mídia e discurso de crise. Boletim IBCCRIM, São Paulo, v. 26, n. 311, p. 12-13., out. 2018.

DE ALMEIDA, Frankarles Genes et al. A importância do método de Associação e Proteção Aos Condenados (APAC) para o sistema prisional brasileiro. Revista Direito \& Dialogicidade, v. 3, n. 1, 2013.

DE ASSIS MOURA, Maria Thereza Rocha. A Nova sistemática das medidas cautelares pessoais no processo penal brasileiro. SUPERIOR TRIBUNAL DE JUSTIÇA, p. 139, 2014. 
DIAS, Sandro; DE OLIVEIRA, Lourival José. A Reinserção Social Através do Trabalho: Responsabilidade Empresarial no Resgate da Dignidade da Pessoa Humana. Revista Jurídica Cesumar-Mestrado, v. 14, n. 1, 2014.

DO PRADO AMARAL, Cláudio. Um novo método para a execução da pena privativa de liberdade. Revista de Informação Legislativo, v. 53, n. 209, 2016.

FONSECA, Daniel Naiff da. Considerações críticas sobre o atual modelo ressocializador de execução penal. Disponível na internet: www.ibccrim.com.br, 15.06.2001.

FERREIRA, V., e OTTOBONI, M. Método APAC: Sistematização de processos. Belo Horizonte: Tribunal do Estado de Minas Gerais. (2016). p. 20. Disponível em: <https://bd.tjmg.jus.br/jspui/bitstream/tjmg/7821/1/APAC.pdf> Acesso em: 29 ago. 2019.

FERREIRA, Viviane Gonçalves. Governança colaborativa na prática: uma análise das experiências nas APACs. 2015. Tese de Doutorado.

GARLAND, David. Mass Imprisonment: Social Causes and Consequences. Londres: Sage Publications, 2001.

GARLAND, David. The Culture of Control: Crime and Social Order in Contemporary Society. Chicago: The University Of Chicago Press, 2001.

JÚNIOR, Roberto Delmanto. 25 anos de Lei de execução Penal. Boletim 201. Agosto/2009. Disponível em: <https://www.ibccrim.org.br/boletim_artigo/3921-25-anos-de-Lei-de-ExecucaoPenal>. Acesso em: 12/08/2019.

LOPES JR, Aury; PAIVA, Caio. Audiência de custódia e a imediata apresentação do preso ao juiz: rumo à evolução civilizatória do processo penal. Revista Liberdades, n. 17, 2014.

LOPES, Rosalice. Prisioneiras de uma mesma história: o amor materno atrás das grades. Tese (doutorado em psicologia) Universidade de São Paulo, São Paulo, 2004. p. 18

MAIA, Luciano Mariz. O Brasil antes e depois do Pacto de San José. Boletim Científico-Escola Superior do Ministério Público.

MARONNA, Cristiano. Política de Drogas, Cultura do controle e Propostas Alternativas. São Paulo: Instituto Brasileiro de Ciências Criminais, 2011.

MINISTÉRIO DA JUSTIÇA E SEGURANÇA PÚBLICA. Departamento Penitenciário Nacional. Levantamento Nacional de Informações Penitenciárias (INFOPEN). Brasília: 2017. Disponível em: <http://depen.gov.br/DEPEN/depen/sisdepen/infopen/relatorio_2016_22-11.pdf〉. Acesso em: 19 ago. 2019.

MUNIZ, Vera Lúcia Travençolo \& LISBÔA, Eli Queiroz. O Sistema Penitenciário: razões históricas, sociais e jurídicas da falência do sistema prisional brasileiro quando da ressocialização do preso. Relatório Final de Pesquisa do PIBC/CNPq - UFV. 
PASTANA, Débora Regina. Estado punitivo brasileiro. A indeterminação entre democracia e autoritarismo. Civitas-Revista de Ciências Sociais, v. 13, n. 1, 2013. p. 36.

PEDROSO, Regina Célia. Utopias penitenciárias projetos jurídicos e realidade carcerária no Brasil. Revista de História, n. 136, p. 121-137, 1997.

PIOVESAN, Flavia. Direitos sociais, econômicos e culturais e direitos civis e políticos. Emilio García Méndez, 2004, p. 22.

SHECAIRA, S.S. Tolerância zero. Revista Brasileira de Ciências Criminais, São Paulo: IBCCrim/RT, n. 77, p. 261-280, 2009.

SILVA, Jane Ribeiro (org.). A execução penal à luz do método APAC. Belo Horizonte: Tribunal de Justiça do Estado de Minas Gerais, 2012.

SILVEIRA, VALDIR JOÃO. A realidade dos presídios na visão da Pastoral Carcerária. estudos avançados, v. 21, n. 61, p. 209, 2007. Disponível em: <http://www.scielo.br/scielo.php?pid=S010340142007000300014\&script=sci_arttext\&tlng=pt $>$ Acesso em: 08 set. 2019.

SUPREMO TRIBUNAL FEDERAL. 1a Turma. HC 72.992/96. Rel. Min. Celso de Mello. v.u. DJ de 14.11.96.

TJPR - TRIBUNAL DE JUSTIÇA DO ESTADO DO PARANÁ. Método adotado no Paraná faz com que índice de ressocialização de presos salte de 14\% para 91\%. Paraná: TJPR, 2017. Disponível em: $<$ https://www.tjpr.jus.br/destaques/-/asset_publisher/11KI/content/metodo-adotado-no-parana-fazcom-que-indice-de-ressocializacao-de-presos-salte-de-14-para-91-/18319?inheritRedirect=false >. Acesso em 01 set. 2019.

VIEIRA, Oscar Vilhena; DUPREE, A. Scott. Reflexões acerca da sociedade civil e dos direitos humanos. 2004.

WACQUANT, Loïc. As prisões da miséria. Tradução André Telles; tradução à introdução da introdução à segunda edição e do prefácio Maria Luiza X. de A. Borges. 2 ed. Rio de Janeiro: Zahar. 2011.

YAROCHEWSKY, Leonardo. Ressocialização, reintegração, reeducação ou recuperação do condenado: uma grande farsa. São Paulo, 20 jun 2005. Disponível em: <www.ibccrim.org.br〉, Acesso em: 20 ago 2019. 